\title{
Avicenna Latinus, Liber primus naturalium: Tractatus tertius de his quae habent naturalia ex hoc quod habent quantitatem, edited by Jules Janssens. Brussels, Académie Royale de Belgique, 2017, vi + 22* 161 pp., ISBN: 9782803106189 . Cloth $€ 84$
}

Review by ANDREAS LAMMER

Universität Trier, DE

lammer@uni-trier.de

The Avicenna Latinus series has long become a reliable institution in our studies of the philosophy of Avicenna and its influence upon Latin scholasticism. The series is known for its philological rigor, for its meticulous comparison of the Latin text with the Arabic original, and for its complete and exceptionally rich documentation (three apparatus; doctrinal, editorial, and philological introductions; and a double glossary).

It is much lesser known for having been incomplete. Having been the personal accomplishment of more than twenty-five years of investigation by the Belgium scholar Simone Van Riet, its effective completion was thwarted by her passing in 1993, leaving the edition of the physics section of the Latin version of Avicenna's magnum opus uncompleted. This sad incident put the whole enterprise at peril. As André Allard explained in his preface to the 2006 - nota bene the gap of thirteen years! - publication of the second volume of Avicenna's Latin Physics: «l'avenir de la collection paraissait fort sombre.» What was to become of Van Riet's unfinished work on the rest of the Physics? Who would continue the edition? - And perhaps even more importantly: How would it be continued, i.e., what should be the guiding goal of the future efforts in continuing (and completing) the series, should there be any such future efforts in the first place? A diplomatic edition? A critical edition? Or a full Avicenna-Latinus-edition - «périlleuse mais exaltante», as Allard put it - which complies with the high standards of the previous volumes in the series?

Luckily, Allard together with the "Administrative Committee of the Avicenna Latinus» at the Académie Royale de Belgique and Jules Janssens - the editor of the volume under review here - were pushing towards the third option. Based on Van Riet's work, Allard and Janssens saw to the aforementioned publication of the second volume in 2006 and began to prepare the edition of the badly transmitted text for the third volume. Allard did not live long enough to see its publication; his passing in 2014 was another major drawback for the project. Thus, what we should celebrate, first and foremost, is the fact that with the volume under review, Janssens completed, and he did so successfully, what Van Riet started and what Allard rescued. ${ }^{1}$ They, all together, did a great service to the

${ }^{1}$ Gérard Verbeke also contributed to nine of the volumes by writing the often detailed doctrinal introductions. Moreover, it is announced in the preface of the present book that Jannsens is in the process of preparing the glossaries to the Latin physics of Avicenna, to be published as a separate volume. 
study of medieval Arabic and Latin philosophy; and this reviewer is immensely grateful to them for all the efforts - «périlleuse mais exaltante» - during the last fifty years.

Overall, the textual situation of the tractatus tertius of Avicenna's Sufficientia, i.e., the third book of the Latin version of the physics of his al-Šifä' («The Cure»), is very different from, not to say largely incomparable to, that of the preceding two tractatus. While Van Riet, as she explained in detail in her introduction to the first volume of the Sufficientia, assessed twenty-two manuscripts, determined two different redactions, decided to edit redaction $\mathrm{A}$, and selected three primary witnesses (D, P, and V), ${ }^{2}$ Janssens did no such thing for the present volume; but he also did not have to, because the text transmitted by the twenty-two witnesses breaks off in mid-sentence after only eighty lines in the present edition, i.e., after roughly one quarter of the first chapter. ${ }^{3}$ The remaining text, which is likewise incomplete (omitting chapters eleven to fourteen), is only transmitted through one single witness: the rather late Ms. Vatican: Biblioteca Apostolica, Urb. lat. 186 from the fifteenth century (originally grouped by Van Riet as containing redaction B). In addition, the remaining text is the result of a later translation: while the first two tractatus, and the first eighty lines of the third, had been translated in Toledo in the twelfth century by Dominicus Gundisalvi, ${ }^{4}$ the remaining chapters were translated a hundred years later in Burgos upon request of the local Bishop Gonzalo Garcia Gudiel. The precise reasons why the translation of the third tractatus of Avicenna's Sufficientia was continued in the thirteenth century and why it was discontinued again after finishing ten of fourteen chapters are unknown. Janssens considers, and rejects, a number of possibilities in the introduction. According to him, the only viable hypothesis is that the Parisian condemnations of 1277 played their part in putting an end to the translation efforts that concerned Avicenna's Sufficientia (p. $4^{*}$ ). Whether or not this hypothesis can be sustained needs to be seen.

Objectively, this is in its entirety a poor situation for a critical edition - but this is all we have, and it is what Janssens had to cope with and to struggle through in preparing the edition. So, from 387.63 onwards, the apparatus contains only those readings from Ms. Vat. Urb. lat. 186 which Janssens rejected for his own emendations. In his introduction, Janssens explains his decision to follow Van Riet's earlier advice that an edition of a text preserved in only one witness should not simply reproduce that witness with all its faults but, instead, should provide a useful tool to serve the scholarly community (p. $\left.6^{*}\right)$. Consequently, Janssens decided to correct the transmitted text and, thus, was required to

\footnotetext{
${ }^{2} \mathrm{D}=$ Ms. Dubrovnik, Dominikanski samostan, 20 (36-V-5); $\mathrm{P}=$ Ms. Paris, Bibliothèque nationale, lat. 16604; and V = Ms. Venice, Biblioteca Marciana, lat. 2665.

${ }^{3}$ In this review I shall follow the Latin chapter counting. The Latin edition treats the first chapter of the Arabic text as a prologue, thus counting the second chapter of the Arabic as the first chapter of the book etc. Interestingly, the 1508 Venice edition follows the original Arabic counting. ${ }^{4}$ cf. Hasse, D.N., and Büttner, A., «Notes on Anonymous Twelfth-Century Translations of Philosophical Texts from Arabic into Latin on the Iberian Peninsula», in D.N. Hasse and A. Bertolacci, ed., The Arabic, Hebrew and Latin Reception of Avicenna's Physics and Cosmology, Berlin / Boston, Walter de Gruyter, 2018, S. 313-369.
} 
discern mistakes and word choices that derive from the activity of the translator (which are to be retained) from mistakes and errors that are the result of the subsequent activity of later scribes (which are to be emended). There is sometimes only a very thin line between the two cases and Janssens overall should be congratulated for his rigour, even though there are, occasionally, decisions that are not relatable. Why, for example, did Janssens opt «pour une correction d'auteur» and changed gravitas to inclinatio in 439.256? The former lectio is certainly surprising here (especially given the accurate translation of mayl as inclinatio two lines earlier and elsewhere), but it is certainly not «dépourvue de sens», as Janssens claims. As another example, was it really necessary to change ambabus in 483.8 to omnibus? One could consider a misreading of pronouns on behalf of the translator, a different lectio in the Arabic source, or an interpretative translation in light of the subsequent example that relies on a line extending in two directions. In both examples, Janssens' ambition to avoid the perils of a diplomatic edition went a bit too far, it seems. If we wish to examine the terminology employed by the Arabic-Latin translators, and if the edition under review is supposed to enable us (among other things) to do precisely this, then we need to acknowledge gravitas, alongside inclinatio, as a possible choice to render mayl into Latin. (Yet, this is no serious point of criticism, because even if one is not in agreement with Janssens' emendations, the apparatus always provides the original manuscript readings anyway.)

Regarding the first eighty lines, for which Janssens had multiple witnesses at his disposal, there are a few suggestions I would like to make:

- $\quad$ ad 379.13 (app. 3): It seems more likely that the translator read mā instead of $h \bar{a}$ (not instead of -hi as Janssens suggested) - in which case -hā would be a new, so far unattested, variant for the Arabic text: wa-immā min ğihat al-qiyās ilā 'adad mā yașdiru 'anhā aw miqdārihā.

- $\quad$ ad 380.15 (app. 2/3): It seems probable that the translator's source might have lacked li-l-ăgsām min (Janssens does not comment on this in particular).

- ad 381.22 (app. 1): consideratur ] corr. considerantur V D P - I reject the correction Janssens made (i) against all his witnesses; (ii) despite leaving considerantur «uncorrected» in the plural in an earlier construction in 1.15; and (iii) while claiming (rightly) «le latin calque la tournure de la phrase arabe» thus implying - or assuming (wrongly) - that the Arabic editions unambiguously provide a singular verb (yu 'tabaru). A singular verb, indeed, is given in Zāyid's edition, yet the other two available editions of the Arabic, by McGinnis and by Āl Yāsīn, provide tu 'tabaru, which corresponds to the plural considerantur rejected by Janssens. (Of the two Arabic manuscripts at this reviewer's disposal, Ms. Leiden or. 84 also gives the singular, whereas Ms. Leiden or. 4, though not entirely clear, may seem to incline towards the plural.) Admittedly, in the preceding construction in 1.20 we already found singular consideratur (this time, though, in agreement with Ms. Leiden or. 84, while Ms. Leiden or. 4 is undotted), whereas all Arabic editions provide plural tu tabaru (without any comment from Janssens, besides «[1] a traduction calque littéralement la tournure 
de l'arabe»). It is, thus, certainly possible that the translator, having changed the numerus in 1.20 already, proceeded the same way here in 1.22 , too. This, at least, seems to be Janssens assumption, and he may well refer to Zāyid's edition in support. However, Janssens decision to go against all three Latin witnesses (and, as one might add, also against the Venice edition of 1508) as well as the two newer editions of the Arabic is questionable and unnecessary. In discussing the discrepancies between the Arabic and the Latin, more complete or detailed comments would have been welcome here and, in fact, in the entire second half of the difficult and complex prologue (esp. in the second half beginning in 1.15 with Sed varietates respectuum ... = wa-ahwäl allati ...).

- ad 381.23 (app. 2): si ] كيف (quomodo) - si perhaps was not meant to translate kayfa but could also have been the result of alternative readings (e.g., in for annahā or hal for kayf?).

Janssens is also interested in improving the textual situation of the Arabic and offers an annexe containing a number of welcome suggestions to Zāyid's edition $\left(13^{*}-19^{*}\right)$. Most of these are helpful, some of these correspond to the improved text in Āl Yāsīn's edition (not mentioned by Janssens here), few smaller corrected readings, however, possibly go back (I can only assume) to Janssen's reliance on an inaccurate reprint version of Zāyid's edition of Avicenna's text. In these widely distributed reprints, not rarely of low quality, some of the dots may not always be discernible, even though in the original print from 1983 they were. Such seems to be the case, for example, in Janssens' reading mumkin in 179.2, rightly suggesting to read yumkinu instead, while the original Arabic in fact has a form of yumkinu; it occasionally happens that some of the crucial dots are no longer visible in available reprints. Other occasional inaccuracies include his correction of 179.3 (which should be switched around, so that the lecture actuelle is țarafihuma and the leçon corrigée is țarafayhumā); the misspelled šay' in 180.1; and the jumbled-up reference «1817,2» (which should be «182, 17») - but these are trifles.

What I lament, though, is the absence of an introduction doctrinale. The two earlier volumes of the physics of Avicenna Latinus - as all other volumes of the series - were accompanied by an (often) elaborate survey of their contents by Gérard Verbeke. That Janssens, who would have been very much qualified to provide an insightful introduction, abstained from including an exposition of the themes and arguments contained in the edited section of text is all the more regrettable as the third book of Avicenna's physics has not yet received a full treatment. Even this reviewer's own recent monograph, The Elements of Avicenna's Physics, focused, by and large, on books one and two. Of course, there are a number of investigations of certain key aspects of Avicenna's views in the third book, especially his rejection of atomism, but a coherent reading of the third book in toto still remains to be written now.

Apart from the above points of criticism, Janssens has produced a marvellous piece of scholarship that finally completes the Latin translation of Avicenna's major work on physics. This is an outstanding achievement not only in itself but also in light of the 
publication history within the Avicenna Latinus series - and it will be crowned, hopefully, by the additional glossary volume which Janssens already promised and to which this reviewer is now looking forward.

As so often before, the publishing house Peeters has distributed a beautiful book, solid, and of high quality. This reviewer would have said «flawless» had his copy not the wrong title on its spine - but that is a trifle. 